Elsevier required licence: (C) <2018>. This manuscript version is made available under the CC-BY-NC-ND 4.0 license http://creativecommons.org/licenses/by-nc-nd/4.0/ 
Research article

\title{
A hybrid constructed wetland for organic-material and nutrient removal from sewage: Process performance and multi-kinetic models
}

\author{
I. Cuong Nguyen a, , S. Woong Chang ${ }^{\mathrm{c}}$, Thi Loan Nguyen ${ }^{\mathrm{a}}$, H. Hao Ngo ${ }^{\mathrm{d}}$, Gopalakrishnan Kumar , \\ J. Rajesh Banuf ${ }^{\mathrm{f}}$ M. Cuong Vu ${ }^{\mathrm{g}}, \mathrm{H}$. Sinh Le ${ }^{\mathrm{g}}$, D. Duc Nguyen ${ }^{\mathrm{h}, \mathrm{i}, *}$ \\ ${ }^{a}$ Faculty of Environmental Sciences, Hanoi University of Science, Vietnam National University, Hanoi, Viet Nam \\ ${ }^{\mathrm{b}}$ Faculty of Environmental Engineering Technology, Hue University, Quang Tri Campus, Viet Nam \\ ${ }^{c}$ Department of Environmental Energy \& Engineering, Kyonggi University, 94 San, Iui-dong, Youngtong-gu, Suwon-si 442-760, Gyeonggi-do, Republic of Korea \\ ${ }^{\mathrm{d}}$ Centre for Technology in Water and Wastewater, School of Civil and Environmental Engineering, University of Technology, Sydney (UTS), Australia \\ e Department of Environmental Engineering, Daegu University, Republic of Korea \\ ${ }^{\mathrm{f}}$ Department of Civil Engineering, Regional Campus of Anna University, Tirunelveli, 627007, Tamil Nadu, India \\ ${ }^{\mathrm{g}}$ Institute of Research and Development, Duy Tan University, Da Nang, Viet Nam \\ ${ }^{\mathrm{h}}$ Department for Management of Science and Technology Development \& Faculty of Environment and Labour Safety, Ton Duc Thang University, Ho Chi Minh City, \\ Vietnam \\ ${ }^{i}$ Department of Environmental Energy Engineering, Kyonggi University, Republic of Korea
}

\section{A RTICLE INFO}

\section{Keywords:}

Predictive model

Multiple regression

Hybrid constructed wetland

Kinetic constant

Hydraulic loading rate

\begin{abstract}
A B S T R A C T
A pilot-scale hybrid constructed wetland with vertical flow and horizontal flow in series was constructed and used to investigate organic material and nutrient removal rate constants for wastewater treatment and establish a practical predictive model for use. For this purpose, the performance of multiple parameters was statistically evaluated during the process and predictive models were suggested. The measurement of the kinetic rate con- stant was based on the use of the first-order derivation and Monod kinetic derivation (Monod) paired with a plug flow reactor (PFR) and a continuously stirred tank reactor (CSTR). Both the Lindeman, Merenda, and Gold (LMG) analysis and Bayesian model averaging (BMA) method were employed for identifying the relative im- portance of variables and their optimal multiple regression (MR). The results showed that the first-order-PFR $\left(\mathrm{M}_{2}\right)$ model did not fit the data $\left(P>0.05\right.$, and $\left.R^{2}<0.5\right)$, whereas the first-order-CSTR $\left(\mathrm{M}_{1}\right)$ model for the chemical oxygen demand $\left(\mathrm{COD}_{\mathrm{Cr}}\right)$ and Monod-CSTR $\left(\mathrm{M}_{3}\right)$ model for the COD $\mathrm{Cr}$ and ammonium nitrogen $\left(\mathrm{NH}_{4}-\mathrm{N}\right)$ showed a high correlation with the experimental data $\left(R^{2}>0.5\right)$. The pollutant removal rates in the case of $\mathrm{M}_{1}$ were $0.19 \mathrm{~m} / \mathrm{d}$ $\left(\mathrm{COD}_{\mathrm{Cr}}\right.$ ) and those for $\mathrm{M}_{3}$ were $25.2 \mathrm{~g} / \mathrm{m}^{2} \cdot \mathrm{d}$ for $\mathrm{COD}_{\mathrm{Cr}}$ and $2.63 \mathrm{~g} / \mathrm{m}^{2} \cdot \mathrm{d}$ for $\mathrm{NH}_{4}-\mathrm{N}$. By applying a multi-variable linear regression method, the optimal empirical models were established for predicting the final effluent concentration of five days' biochemical oxygen demand (BOD 5 ) and $\mathrm{NH}_{4}-\mathrm{N}$. In general, the hydraulic loading rate was considered an important variable having a high value of relative importance, which appeared in all the optimal predictive models.
\end{abstract}

\section{Introduction}

The processes of eliminating organic matter and nutrients from polluted wastewaters are quite complicated. They include chemical, physical, and biological factors that demand triply synergistic processes for maximum efficiency. These factors of the constructed wetland (CW) affect the removal efficiency and are affected by shifting local and regional conditions (Gholizadeh et al., 2015; Vo et al., 2018; Vo et al., 2017; Wu et al., 2018a; b). As a result, an appropriate CW design that compares favorably to those of other studies is more difficult to achieve. The misunderstanding of the contaminant dynamics of this system can lead to design failures that usually cause a degraded efficiency of the targeted pollutants' removal, clogging, and short circulation in the design's fluid dynamics (Davoodi et al., 2016; Samsó et al., 2016; Wu et al., 2018a; b). Therefore, the application of the knowledge of pol- lutant removal kinetics to this data could be expected to ensure positive results if and when these conclusions are effectively applied to the engineering challenges of $\mathrm{CW}$ design.

There are several models and methods for predicting pollution removal, and the first-order model (Chan et al., 2008; Trang et al., 2010) and linear regression (Babatunde et al., 2011b; Gholizadeh et al., 2015; Reed and D., 1995; Sheridan et al., 2013) are popular. Some approaches

\footnotetext{
* Corresponding author. Ton Duc Thang University, Ho Chi Minh City, Vietnam.

E-mail address: nguyendinhduc@tdt.edu.vn (D.D. Nguyen).
} 
recommended recently are the use of artificial neural networks, multicomponent reactive transport module, principal component analysis, clustering tree diagrams, classification and regression trees, and redundancy analysis (Akratos et al., 2008; Babatunde et al., 2011b; Dong et al., 2012; Hijosa-Valsero et al., 2011; Huang et al., 2014). However, these may prove to be overly complicated owing to their numerous empirical parameters.

The multiple regression (MR) method has been considered useful for simplified description, analysis of CW performance, and developing predictive models (Murray-Gulde et al., 2008; Tomenko et al., 2007). The majority of the previous studies that were focused on the evalua- tion of the efficacy of MR (Babatunde et al., 2011b; Chan et al., 2008; HijosaValsero et al., 2011) used the response variables of the effluent concentrations while avoiding the application of the removal rate.

To accurately compute $\mathrm{MR}$, the relative importance and optimal models of the given predictors are required, in which relative importance is the proportionate contribution each predictor makes to $R^{2}$ (Johnson, 2000). For selecting the optimal models, the previous research was based primarily on $R^{2}$ (Babatunde et al., 2011b; HijosaValsero et al., 2011). However, their methods did not involve the evaluation of the interaction analysis and multi-collinearity, which can influence the accuracy of these results. When a model has a large number of variables, it results in a higher $R^{2}$ value, which might cause over-fitting. Bayesian model averaging (BMA) is considered to be a good tool for overcoming these limits. By performing averaging over several different competing models, BMA integrates model uncertainty

into the prediction and estimation of the parameters (Fang et al., 2016; Hoeting et al., 1999).

In this work, we used the new technique of BMA to overcome multi-

collinearity and obtain the precise $R^{2}$ value. The obtained results clarified the relative importance of the influent factors of a hybrid constructed wetland $(\mathrm{HCW})$, and the optimal models that have not been

adequately addressed in previous studies were also selected. Furthermore, by applying more response variables such as hydraulic loading rates (HLRs), we developed more effective and accurate predictive models that contributed significantly in the design, management, and maintenance of the HCW system.

The main purpose of this study is to clarify the performance of the HCW and explore the predictive models using kinetics and MR. This study is mainly focused on the comparison of the kinetics, weighting correlation, and relative importance and the development of optimal predictive models for HCW performance using the BMA method.

\section{Materials and methods}

\subsection{Description of hybrid constructed wetland and data collection}

To clarify the adaptation and removal performance of HCW, a pilot system was installed at the sewage treatment plant of Dong Ha city,

Vietnam, and was then tested in over an operating period of 190 days. The sewer at this location collects the municipal wastewater and runoff water from Dong Ha city. The water level of this sewer fluctuates from

$0.5 \mathrm{~m}$ in the dry season to $0.9 \mathrm{~m}$ in the wet season. The average water flow in the sewer is $181,400 \mathrm{~m}^{3} / \mathrm{d}$ with a mean velocity of $1.5 \mathrm{~m} / \mathrm{s}$. The pilot HCW system included a vertical flow (VF) (planted with Canna indica at a density of 20-25 plants $/ \mathrm{m}^{2}$ ) and a horizontal flow (HF) (planted with Colocasia esculenta at a density of 15 plants $/ \mathrm{m}^{2}$ in series layers of various particle sizes. The filter layers comprised various gravel grades with the total height of the VF being $0.7 \mathrm{~m}$ and that of the HF being $0.5 \mathrm{~m}$. This corresponded to $2.65,1.32$, and 1.76 days of hydraulic retention times for $\mathrm{HLR}_{1}, \mathrm{HLR}_{2}$, and $\mathrm{HLR}_{3}$, respectively. More details of the characteristics of the sewage, HCW, and operating procedures are described in a previous report by Nguyen et al. (2017).

Wastewater samples were collected from the influent of the VF (SP1) and effluent of the VF (SP2) and HF (SP3) as shown in Fig. 1 (Nguyen et al., 2017). The sampling rate was once a week for more than 6 months of operation. Twenty-three water samples of HCW were ob- tained and tested in this experiment. The $\mathrm{pH}$ was determined using a multiparameter water quality meter (HQ40d, Hach, USA). The $\mathrm{COD}_{\mathrm{Cr}}, \mathrm{BOD}_{5}$, total suspended solids (TSS), $\mathrm{NH}_{4}-\mathrm{N}$, nitrate nitrogen $\left(\mathrm{NO}_{3}-\mathrm{N}\right)$, phosphate $\left(\mathrm{PO}_{4}-\mathrm{P}\right), \mathrm{TN}$, and total coliforms (TCol) were analyzed according to the Standard Methods 5220D, 5210B, 2540D, 4500- $\mathrm{NH}_{3} \mathrm{~F}$, 4500- $\mathrm{NO}_{3}$ B, 4500-P D, 4500-P J, and 9221 B, respectively (APHA/ WEF/AWWA, 2005). The spectrophotometer (Cary 60, Agilent Technologies Inc., USA) was used to measure the $\mathrm{COD}_{\mathrm{Cr}}, \mathrm{NH}_{4}-\mathrm{N}, \mathrm{NO}_{3}-\mathrm{N}$, and $\mathrm{PO}_{4}-\mathrm{P}$.

Owing to the intermittent flow, the aerobic and anoxic conditions were dominant in the HCW. Oxygen is a terminal electron acceptor that is reduced while electron donors (mainly organic matter and ammonia) are oxidized, and $\mathrm{CO}_{2}$ and $\mathrm{H}_{2} \mathrm{O}$ are formed as end products (1). In the bottom layers of the $\mathrm{HCW}$, other reactions $(2,3$, and 4$)$ might occur in response to the decrease in oxygen and the redox potential (Kadlecand Wallace, 2009).

$\mathrm{CH}_{2} \mathrm{O}+\mathrm{O}_{2} \rightarrow \mathrm{CO}_{2}+\mathrm{H}_{2} \mathrm{O}$

$5 \mathrm{CH}_{2} \mathrm{O}+4 \mathrm{NO}_{3}^{-} \rightarrow 2 \mathrm{~N}_{2}+4 \mathrm{HCO}_{3}^{-}+\mathrm{CO}_{2}+3 \mathrm{H}_{2} \mathrm{O}$

$\mathrm{CH}_{2} \mathrm{O}+3 \mathrm{CO}_{2}+\mathrm{H}_{2} \mathrm{O}+2 \mathrm{MnO}_{2} \rightarrow 2 \mathrm{Mn}^{2+}+4 \mathrm{HCO}_{3}^{-}$

$\mathrm{CH}_{2} \mathrm{O}+4 \mathrm{SO}_{4}^{2-} \rightarrow \mathrm{H}_{2} \mathrm{~S}+2 \mathrm{HCO}_{3}^{-}$

\subsection{Kinetic models}

The first-order and Monod kinetic models were used to describe and evaluate the pollution degradation in this study. The hydrodynamic pattern in the HCW was considered to be the same as that of the plug flow reactor (PFR) and continuously stirred tank reactor (CSTR). Therefore, the new models have been developed by integrating the firstorder and Monod models with PFR and CSTR.

\subsubsection{First-order $k-C^{*}$ model with PFR $\left(M_{1}\right)$}

By assuming an exponential removal rate to reflect a non-zero background wetland concentration $\left(C^{*}\right)$ (Ali et al., 2018; Kadlec and Knight, 1996), the removal model based on the first-order and $C^{*}$ models is expressed as follows (Eq. (5):

$k_{l}=H L R \times \operatorname{Ln} \frac{C_{i}-C^{*}}{C_{o}-C^{*}}$

\subsubsection{First-order model with CSTR $\left(\mathrm{M}_{2}\right)$}

To model the correlation between the influents and effluents of $\mathrm{CW}$ for nutrients and organic matter, the integrated model that combined first-order kinetics with CSTR (Saeed and Sun, 2011) was established. The combined model is expressed as shown in Eq. (6): 
the VF and denitrification in the HF in order to reduce the nutrient content in the effluent. Wastewater was pumped from the sewage system (twice a day for an interval of $30 \mathrm{~min}$ ), stored in the storage

tank, and was allowed to flow intermittently to the VF at various HLRs of $0.44 \mathrm{~m}^{3} / \mathrm{d}$ (first stage, $\mathrm{HLR}_{1}$ ), $0.88 \mathrm{~m}^{3} / \mathrm{d}$ (second stage, $\mathrm{HLR}_{2}$ ), and $0.66 \mathrm{~m}^{3} / \mathrm{d}$ (final stage, $\mathrm{HLR}_{3}$ ). The effluent of the VF was drained continuously by gravity into the HF tank. The characteristics of the VF and HF are presented in Table 1. Each tank was built with three filter
$k_{2}=\frac{H L R \times\left(C_{i}-C_{0}\right)}{C_{0}}$

2.2.3. Monod kinetics with CSTR $\left(M_{3}\right)$

This model combined the Monod kinetics, which comprises half the saturation constant of the limiting substrate and effluent concentration, with the CSTR flow pattern (Saeed and Sun, 2011). It is expressed as shown in Eq. (7): 


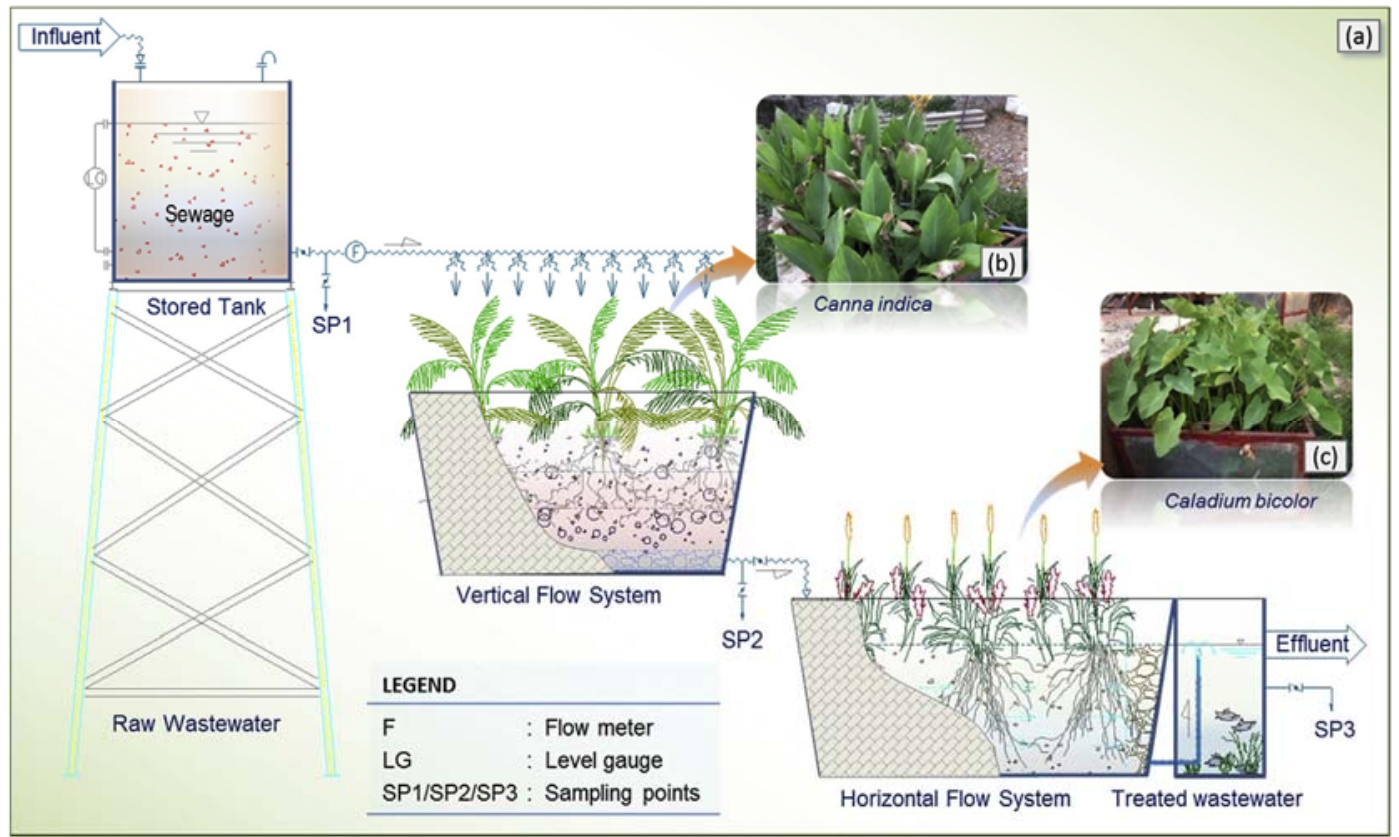

Fig. 1. HCW system (a) and photographs of Canna indica (b) and Colocasia esculenta (c).

Table 1

Characteristics of hybrid constructed wetland.

\begin{tabular}{|c|c|c|c|}
\hline Parameter & VF & $\mathrm{HF}$ & VF-HF \\
\hline System type & $\begin{array}{l}\text { Subsurface vertical } \\
\text { flow }\end{array}$ & $\begin{array}{l}\text { Subsurface } \\
\text { horizontal flow }\end{array}$ & $\begin{array}{l}\text { HCW two } \\
\text { stages }\end{array}$ \\
\hline Length $\times$ width $\times$ height & $1.2 \times 1.2 \times 1.2 \mathrm{~m}$ & $3.0 \times 1.0 \times 1.0 \mathrm{~m}$ & \\
\hline Surface & $1.44 \mathrm{~m}^{2}$ & $3.0 \mathrm{~m}^{2}$ & $4.44 \mathrm{~m}^{2}$ \\
\hline Type of plant & Canna indica & Colocasia esculenta & \\
\hline Depth of filter & $0.7 \mathrm{~m}$ & $0.5 \mathrm{~m}$ & \\
\hline Filter porosity & 0.4 & 0.4 & \\
\hline Average flow & $0.66 \mathrm{~m}^{3} / \mathrm{d}$ & $0.66 \mathrm{~m}^{3} / \mathrm{d}$ & $\begin{array}{l}0.66 \mathrm{~m}^{3} / \\
\mathrm{d}\end{array}$ \\
\hline HLR & $0.46 \mathrm{~m} / \mathrm{d}$ & $0.22 \mathrm{~m} / \mathrm{d}$ & $0.15 \mathrm{~m} / \mathrm{d}$ \\
\hline
\end{tabular}

$\underline{H L R \times(C-C) \times(C+C)}$

$k_{3}=$

$$
\begin{array}{ccc}
{ }^{o} & h & o \\
C_{0} & &
\end{array}
$$

where $k_{1}(\mathrm{~m} / \mathrm{d}), k_{2}(\mathrm{~m} / \mathrm{d})$, and $k_{3}\left(\mathrm{~g} / \mathrm{m}^{2} \cdot \mathrm{d}\right)$ are the first-order removal rate constants, $C_{i}$ is the inlet concentration $(\mathrm{mg} / \mathrm{L}), C_{o}$ is the outlet concentration $(\mathrm{mg} / \mathrm{L}), \mathrm{C}^{*}$ is the background concentration $(\mathrm{mg} / \mathrm{L}), \mathrm{HLR}$ is in $\mathrm{m} / \mathrm{d}$, and $C_{h}$ is half the saturation constant of limiting substrate $(\mathrm{mg} / \mathrm{L})$. Based on the inlet concentrations, as suggested by Kadlec and Wallace (2009), $\mathrm{C}^{*}$ for $\mathrm{BOD}_{5}, \mathrm{COD}, \mathrm{NH}_{4}-\mathrm{N}$, and TN were of $6,10,0$, and $1.5 \mathrm{mg} / \mathrm{L}$, respectively. In addition, the recommended values of $C_{h}$ for $\mathrm{NH}_{4}-\mathrm{N}, \mathrm{COD}$, and $\mathrm{BOD}_{5}$ are $0.05,60$, and $20 \mathrm{mg} / \mathrm{L}$, respectively (Tchobanoglous et al., 2004; Saeed and Sun, 2011; Vaccari et al., 2006).

\subsubsection{Multiple regression}

Multiple regression is a statistical model that has two or more independent (predictor) variables (Darajeh et al., 2016; Katz, 2013). This model was used because the performance of the HCW is influenced by several complicated factors such as climate conditions, hydraulic conditions, plantings, dissolved oxygen levels, microbiota, periodicity, and influent concentrations (Chan et al., 2008). In MR, these factors are expressed as "predictor variables," and the effluent concentrations or removed load is considered to be the "dependent (response) variables". $y=\beta_{0}+\beta_{1} x_{1}+\beta_{2} x_{2}+\ldots+\beta_{p} x_{p}+\varepsilon$

where $y$ is the response variable $\left(C_{o}\right.$ and $\left.L_{r}\right), x_{i, p}$ are the predictor variables $\left(C_{i n}, C_{i b}, L_{i}, C_{i t}, C_{i t s}, C_{i p}\right.$ and $\left.\mathrm{pH}\right), \beta_{i, p}$ are the regression coefficients, and $\varepsilon$ is the random error.

In this study, the Lindeman, Merenda, and Gold (LMG) analysis was

applied to determine relative importance or ranking, and BMA was applied for the optimal model selection process. Consequently, using BMA, the optimal MR models that were based on the Bayesian information criterion (BIC) and $R^{2}$ were selected. In general, the best models have the lowest BIC value with highest adjusted $R^{2}$ (Hoeting et al., 1999).

\subsubsection{Statistical analyses}

All the statistical analyses of this study were performed using the computing environment $R$ (Version 3.4.0). The statistical differences of the experimental results were evaluated through an analysis of var-

The purpose of MR for simulating the operation process of the HCW is to find the correlation between the removal of pollutants and the sys- tem's inherent controlling factors. Therefore, the MR equation is as follows (Eq. (8): 
iance, and a post-hoc test, Tukey's honest significance difference (Tukey HSD) test, was used to compare the means at a 95\% confidence level. The R-package (relaimpo package function) was used to determine the predictor's relative importance using the LMG measure and boot- strapped confidence intervals. This method of BMA, supplemented with the use of the "BMA package", proved useful for selecting the optimal models.

3. Results and discussion

\subsection{System performance}

The results of the VF-HF system after more than 6 months of operation showed that the removal efficiency and the effluents differed as the HLR changed (Figs. 2 and 3, and Table 2). The effluent strengths fit well with the discharge limits in the first and third stages of the mon- itoring period. The means of the effluent concentrations were $87 \pm 10.6 \mathrm{mg} / \mathrm{L}$ of TSS; $31 \pm 13.1 \mathrm{mg} / \mathrm{L}$ of $\mathrm{BOD}_{5} ; 59 \pm 17.2 \mathrm{mg} / \mathrm{L}$ of $\mathrm{COD}_{\mathrm{Cr}} ; 5.3 \pm 3.0 \mathrm{mg} / \mathrm{L}$ of $\mathrm{NH}_{4}-\mathrm{N} ; 8.4$ $\pm 4.3 \mathrm{mg} / \mathrm{L}$ of $\mathrm{NO}_{3}-\mathrm{N}$;

$7.1 \pm 2.7 \mathrm{mg} / \mathrm{L}$ of $\mathrm{TN} ; 0.9 \pm 0.3 \mathrm{mg} / \mathrm{L}$ of $\mathrm{PO}_{4}-\mathrm{P} ;$ and $1485 \pm 1184$ of MPN (most probable number)/100 mL of TCol. The average treatment

efficiencies for TSS, $\mathrm{BOD}_{5}, \mathrm{TN}, \mathrm{NH}_{4}-\mathrm{N}, \mathrm{PO}_{4}-\mathrm{P}$, and $\mathrm{TCol}$ were $28.3 \pm 12.2,74.9 \pm 11.5,79 \pm 7,76.2 \pm 12.9,3.6 \pm 43.7$, and 


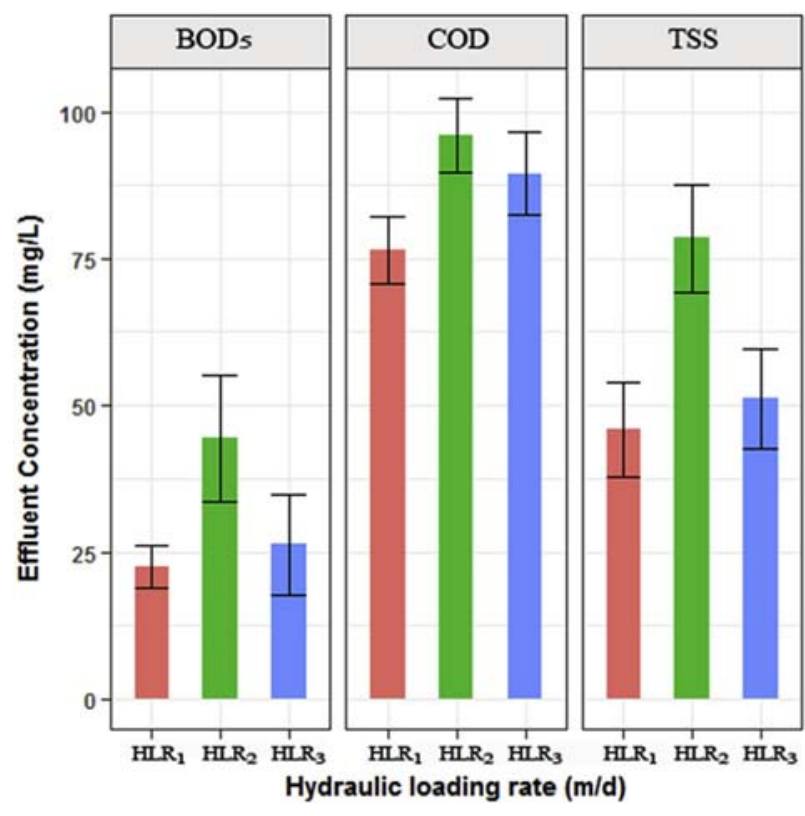

Fig. 2. Error bar (95\% confidence interval) of $\mathrm{BOD}_{5}, \mathrm{COD}$, and TSS.

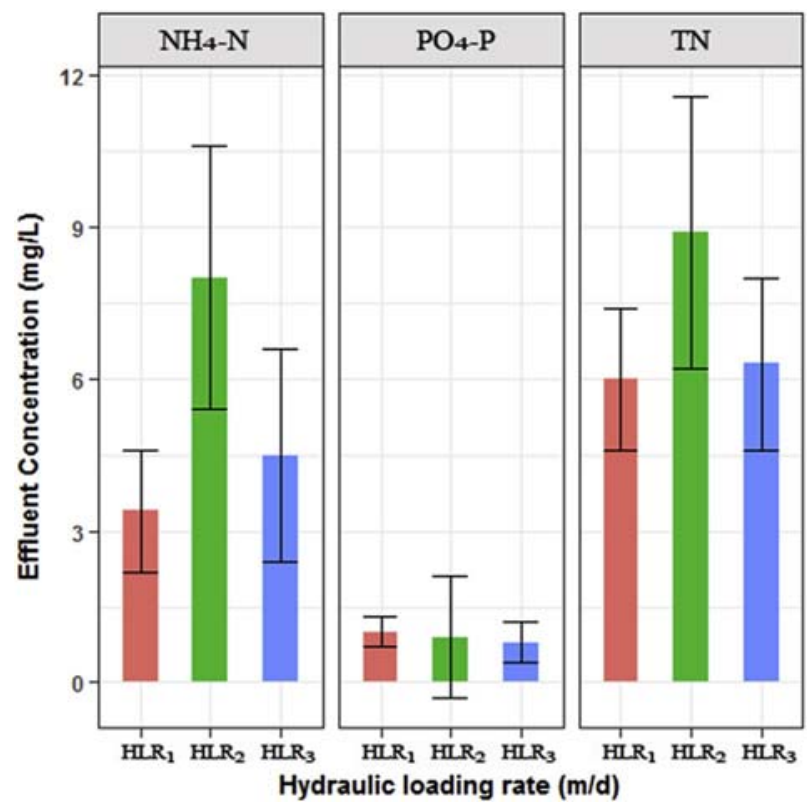

Fig. 3. Error bar (95\% confidence interval) of $\mathrm{NH}_{4}-\mathrm{N}, \mathrm{TN}$, and $\mathrm{PO}_{4}-\mathrm{P}$.
$82 \pm 11.3 \%$, respectively. The reduction in $\mathrm{BOD}_{5}$ and $\mathrm{COD}_{\mathrm{Cr}}$ can be attributed to the biodegradable process that converted the organic matter to water and carbon dioxin in the HCW. In comparison with Vietnam's discharge limits for sewage wastewater $\left(50 \mathrm{mg}-\mathrm{BOD}_{5} / \mathrm{L}\right)$, the average effluent of $\mathrm{BOD}_{5}$ in this experiment was quite low and suitable for disposal into water bodies that were used for agricultural purposes or the equivalent. It is also clear that $\mathrm{TN}$ and $\mathrm{NH}_{4}-\mathrm{N}$ removal were fairly high owing to both the nitrification (the conversion of nitrogen to $\mathrm{NO}_{x}$ in high-oxygen conditions) and denitrification (conversion of $\mathrm{NO}_{x}$ into $\mathrm{N}_{2}$ in low-oxygen conditions) that occur in the HCW (Vymazal, 2005). Furthermore, other mechanisms of nitrogen removal can include assimilation by microbial or plant biomass and adsorption onto the filter as explained by Keffala and Ghrabi (2005). The removal rate of BOD 5 was similar in both tanks (VF and HF), which was approximately $50.9 \%$. The HF unit was considered to have less dissolved oxygen, and yet, it achieved $45 \pm 13.4 \%$ reduction of $\mathrm{NH}_{4}-\mathrm{N}$ and $44 \pm 12 \%$ re- duction of TN. There were statistically significant differences in the effluent concentrations among the three HLRs $(P<0.05)$ except for the case of $\mathrm{PO}_{4}-\mathrm{P}$.

Table 2 presents the inputs and removal efficiency of the system in terms of removal loading rate $\left(L_{r}\right)$ and percentage $(\%)$. $L_{r}$ reached a value of $14.5 \pm 2.7 \mathrm{~g} / \mathrm{m}^{2} \cdot \mathrm{d}$ of $\mathrm{BOD}_{5}\left(30 \mathrm{~g} / \mathrm{m}^{2} \cdot \mathrm{d}\right.$ for the VF unit and $6.9 \mathrm{~g} / \mathrm{m}^{2} \cdot \mathrm{d}$ for the HF unit). The overall TN loading rate reached $4.0 \pm 1.3 \mathrm{~g} / \mathrm{m}^{2} \cdot \mathrm{d}$, with $9.7 \mathrm{~g} / \mathrm{m}^{2} \cdot \mathrm{d}$ for the VF unit, and $1.2 \mathrm{~g} / \mathrm{m}^{2} \cdot \mathrm{d}$ for the HF unit. The removal rates observed in this experiment were rela- tively high as compared with those of the previous studies on HCW. Vymazal and Kröpfelová (2015) obtained $4.5 \mathrm{~g}-\mathrm{BOD}_{5} / \mathrm{m}^{2} \cdot \mathrm{d}$ and $1.2 \mathrm{~g}-\mathrm{TN} / \mathrm{m}^{2} \cdot ; \mathrm{d}$, Melián et al. (2010) reported $14 \mathrm{~g}-\mathrm{BOD}_{5} / \mathrm{m}^{2} ; \mathrm{d}$, Dzakpasu et al. (2011) reported $0.28 \mathrm{~g}-\mathrm{TN} / \mathrm{m}^{2} ; \mathrm{d}$, and Vymazal (2013) reported 2.34-4.24 g$\mathrm{TN} / \mathrm{m}^{2} \cdot \mathrm{d}$.

Although the $\mathrm{PO}_{4}-\mathrm{P}$ removal rate in this study was quite low, the results show that the HCW is a promising technology solution for treating the sewage in order to meet the current Vietnam's standard discharge limits. Based on these influent loading rates and HLR of lower $0.15 \mathrm{~m} / \mathrm{d}$ which tested, this HCW system was found to be suitable for treating sewage in Dong Ha city or similar types of wastewater. In addition, the results obtained for mass-balance analysis during operation of this HCW system at a HLR $0.15 \mathrm{~m} / \mathrm{d}$ indicate that the average pollutant load treatments achieved in VF and HF were $14 \mathrm{~g} / \mathrm{d}$ and $3.58 \mathrm{~g} / \mathrm{d}$ for $\mathrm{TN}, 9.11 \mathrm{~g} / \mathrm{d}$ and $2.58 \mathrm{~g} / \mathrm{d}$ for $\mathrm{NH}_{4}-\mathrm{N}, 0.0 \mathrm{~g} / \mathrm{d}$ and $0.21 \mathrm{~g} / \mathrm{d}$ for $\mathrm{PO}_{4}-\mathrm{P}$, and $39.95 \mathrm{~g} / \mathrm{d}$ and $23.58 \mathrm{~g} / \mathrm{d}$ for $\mathrm{BOD}_{5}$, respectively. However, while TSS removal was not very high, with TSS load removal in VF and HF of $3.63 \mathrm{~g} / \mathrm{d}$ and $20.58 \mathrm{~g} / \mathrm{d}$, respectively. The nutrients, organic matter, and TSS reduced by HCW were attributable to vegetative nutrient uptake, bacterial metabolism, adsorption, and/or accumulation by various forms of mechanical separation, such as layers of filter media. Further information about the simple mass balance estimation in each working unit of this HCW system can be found in supplementary data.

Table 2

Input and effect of HLR on the HCW system performance.

\begin{tabular}{|c|c|c|c|c|c|c|c|}
\hline \multirow[t]{2}{*}{ Parameter } & \multirow[t]{2}{*}{ Influent } & \multicolumn{2}{|c|}{$\mathrm{HLR}_{1}=0.1 \mathrm{~m} / \mathrm{d}$} & \multicolumn{2}{|c|}{$\mathrm{HLR}_{2}=0.2 \mathrm{~m} / \mathrm{d}$} & \multicolumn{2}{|c|}{$\mathrm{HLR}_{3}=0.15 \mathrm{~m} / \mathrm{d}$} \\
\hline & & $L_{r}\left(\mathrm{~g} / \mathrm{m}^{2} \cdot \mathrm{d}\right)$ & Removal efficiency (\%) & $L_{r}\left(\mathrm{~g} / \mathrm{m}^{2} \cdot \mathrm{d}\right)$ & Removal efficiency (\%) & $L_{r}\left(\mathrm{~g} / \mathrm{m}^{2} \cdot \mathrm{d}\right)$ & Removal efficiency (\%) \\
\hline TSS (mg/L) & $123.8 \pm 20.5$ & $3.8 \pm 1.2$ & $33 \pm 8.6$ & $4.3 \pm 2.7$ & $18.0 \pm 10.0$ & $7.6 \pm 3.2$ & $37.0 \pm 9.0$ \\
\hline $\mathrm{BOD}_{5}(\mathrm{mg} / \mathrm{L})$ & $127.7 \pm 11.6$ & $11.1 \pm 1.3$ & $83.2 \pm 3.7$ & $14.8 \pm 2.4$ & $62.4 \pm 9.3$ & $15.8 \pm 1.6$ & $80.0 \pm 6.6$ \\
\hline $\mathrm{COD}_{\mathrm{Cr}}(\mathrm{mg} / \mathrm{L})$ & $186.8 \pm 12.3$ & $14.1 \pm 1.7$ & $76.0 \pm 5.3$ & $19.9 \pm 2.4$ & $56.0 \pm 5.6$ & $21.8 \pm 1.1$ & $74.0 \pm 4.0$ \\
\hline $\mathrm{NH}_{4}-\mathrm{N}(\mathrm{mg} / \mathrm{L})$ & $23.1 \pm 5.8$ & $1.8 \pm 0.4$ & $84.2 \pm 6.6$ & $2.9 \pm 0.8$ & $65.0 \pm 11.5$ & $3.1 \pm 1.1$ & $82.0 \pm 10.5$ \\
\hline $\mathrm{TN}(\mathrm{mg} / \mathrm{L})$ & $33.6 \pm 6$ & $2.7 \pm 0.2$ & $82.0 \pm 4.1$ & $5.0 \pm 0.8$ & $74.0 \pm 7.5$ & $4.2 \pm 1.2$ & $82 \pm 5.0$ \\
\hline $\mathrm{PO}_{4}-\mathrm{P}(\mathrm{mg} / \mathrm{L})$ & $1.05 \pm 0.4$ & $0.0 \pm 0.0$ & $1.3 \pm 40$ & $0.03 \pm 0.06$ & $15.0 \pm 49.0$ & $0.04 \pm 0.07$ & $23.0 \pm 38.0$ \\
\hline TCol (MPN/100 mL) & $8456 \pm 4022$ & & $84 \pm 6$ & & $77 \pm 11$ & & $86 \pm 7$ \\
\hline
\end{tabular}

Average \pm SD: Average \pm standard deviation. 
Table 3

Removal rate constants of three models.

\begin{tabular}{|c|c|c|c|}
\hline $\mathrm{BOD}_{5}$ & $\mathrm{COD}_{\mathrm{Cr}}$ & $\mathrm{NH}_{4}-\mathrm{N}$ & $\mathrm{TN}$ \\
\hline \multicolumn{4}{|c|}{ First-order $k-C^{*}$ model $\left(M_{1}\right)$} \\
\hline$k_{1}=0.24 \pm 0.06$ & $k_{1}=0.19 \pm 0.04$ & $k_{1}=0.42 \pm 0.11$ & $k_{1}=0.3 \pm 0.08$ \\
\hline$R^{2}=0.49$ & $R^{2}=0.51$ & $R^{2}=0.28$ & $R^{2}=0.17$ \\
\hline$P<0.05$ & $P<0.05$ & $P<0.05$ & $P>0.05$ \\
\hline \multicolumn{4}{|c|}{ First-order model with CSTR $\left(M_{2}\right)$} \\
\hline $\begin{array}{l}k_{2}=0.51 \pm 0.2 \\
R^{2}=0.04\end{array}$ & $\begin{array}{l}k_{2}=0.34 \pm 0.1 \\
R^{2}=0.03\end{array}$ & $\begin{array}{l}k_{2}=0.65 \pm 0.43 \\
R^{2}=0.04\end{array}$ & $\begin{array}{l}k_{2}=0.62 \pm 0.24 \\
R^{2}=0.12\end{array}$ \\
\hline \multicolumn{2}{|c|}{$\begin{array}{l}P>0.05 \\
\text { Monod model with CSTR }(M)\end{array}$} & $P>0.05$ & $P>0.05$ \\
\hline & 3 & & \\
\hline$k_{3}=44.4 \pm 13.6$ & $k_{3}=25.2 \pm 5.1$ & $k_{3}=2.63 \pm 1.0$ & \\
\hline$R^{2}=0.30$ & $R^{2}=0.60$ & $R^{2}=0.68$ & \\
\hline$P<0.05$ & $P<0.05$ & $P<0.05$ & \\
\hline
\end{tabular}

\subsection{The kinetic rate constants}

$R^{2}, P$, and $k$ were calculated for each pollutant of $\mathrm{BOD}_{5}, \mathrm{COD} \quad \mathrm{Cr}$ '

$\mathrm{NH}_{4}-\mathrm{N}$, and $\mathrm{TN}$ in three models $\left(\mathrm{M}_{1}, \mathrm{M}_{2}\right.$, and $\left.\mathrm{M}_{3}\right)$, and presented in Table 3. The average influent $\left(C_{i}\right)$ and effluent $\left(C_{\mathrm{o}}\right)$ for $\mathrm{BOD}_{5}, \mathrm{COD}_{\mathrm{Cr}}$, $\mathrm{NH}_{4}-\mathrm{N}$, and $\mathrm{TN}$ were $127.7 \mathrm{mg} / \mathrm{L}$ and $31 \mathrm{mg} / \mathrm{L}, 186.8 \mathrm{mg} / \mathrm{L}$ and $59 \mathrm{mg} /$ $\mathrm{L}, 23.1 \mathrm{~m} / \mathrm{L}$ and $5.3 \mathrm{mg} / \mathrm{L}$, and $33.6 \mathrm{mg} / \mathrm{L}$ and $7.1 \mathrm{mg} / \mathrm{L}$, respectively.

Table 3 shows that $\mathrm{M}_{2}$ does not completely fit the data of all the pollutants $(P>0.05) \cdot R^{2}$ of $\mathrm{M}_{3}$ for $\mathrm{COD}_{\mathrm{Cr}}$ and $\mathrm{NH}_{4}-\mathrm{N}$ were higher than that of the other pollutants and reached values of 0.60 and 0.68 , respectively. This means that the correlation was not coincidental. In general, the models $\mathrm{M}_{1}$ for $\mathrm{COD}_{\mathrm{Cr}}$ and $\mathrm{M}_{3}$ for $\mathrm{COD}_{\mathrm{Cr}}$ and $\mathrm{NH}_{4}-\mathrm{N}\left(R^{2}\right.$ $>0.5$ ), expressed the correlation required for matching the pollution concentrations and operating parameters well.

The pollutant removal rates of model $\mathrm{M}_{1}$ for $\mathrm{COD}_{\mathrm{Cr}}$ was $0.19 \mathrm{~m} / \mathrm{d}$, which is similar to the range mentioned in several studies such as Kadlec and Wallace (2009) and higher than the result obtained by Trang et al. (2010). For an HLR of $0.086 \mathrm{~m} / \mathrm{d}$, Trang et al. (2010) presented $k_{1}$ of $\mathrm{COD}_{\mathrm{Cr}}$ as $0.07 \mathrm{~m} / \mathrm{d}\left(R^{2}=0.7\right)$. For $\mathrm{NH}_{4}-\mathrm{N}$, the value of $k_{3}$ obtained $\left(2.63 \mathrm{~g} / \mathrm{m}^{2} \cdot \mathrm{d}\right)$ is much lower than that $\left(29.8 \mathrm{~g} / \mathrm{m}^{2} \cdot \mathrm{d}\right)$ re-

ported by Saeed and Sun (2011).

\subsection{Correlation analyses and predictive models}

The values of the independent and response variables are presented in Table 4. $\mathrm{COD}_{\mathrm{Cr}}$ changed uniformly with $\mathrm{BOD}_{5}, \mathrm{PO}_{4}-\mathrm{P}$ was primarily influenced by adsorption and desorption, and TN was treated as a lumped category pollutant; therefore, in this study, MR was used for $\mathrm{BOD}_{5}$ and $\mathrm{NH}_{4}-\mathrm{N}$.

Table 4

Values of independent and response variables.

\begin{tabular}{|c|c|c|c|c|}
\hline Parameters & Unit & Minimum & Maximum & Average $\pm \mathrm{SD}$ \\
\hline $\mathrm{pH}$ & - & 7.05 & 7.9 & $7.4 \pm 0.2$ \\
\hline$C_{i t s}$ (TSS inlet concentration) & $\mathrm{mg} / \mathrm{L}$ & 95.0 & 188.0 & $123.8 \pm 20.5$ \\
\hline$C_{i b}$ (BOD 5 inlet concentration) & $\mathrm{mg} / \mathrm{L}$ & 103.0 & 147.0 & $127.7 \pm 11.6$ \\
\hline$C_{i c}$ (COD inlet concentration) & $\mathrm{mg} / \mathrm{L}$ & 165.0 & 206.0 & $186.8 \pm 12.3$ \\
\hline $\mathrm{C}_{\text {in }}\left(\mathrm{NH}_{4}-\mathrm{N}\right.$ inlet & $\mathrm{mg} / \mathrm{L}$ & 12.5 & 39.0 & $23.1 \pm 5.8$ \\
\hline concentration) & & & & \\
\hline$C_{i t}$ (TNinletconcentration) & $\mathrm{mg} / \mathrm{L}$ & 22.0 & 50.2 & $33.6 \pm 6.0$ \\
\hline$C_{i p}\left(\mathrm{PO}_{4}-\mathrm{P}\right.$ inlet concentration $)$ & $\mathrm{mg} / \mathrm{L}$ & 0.03 & 0.38 & $1.05 \pm 0.4$ \\
\hline $\begin{array}{l}C_{o b}\left(\mathrm{BOD}_{5} \text { outlet }\right. \\
\text { concentration })\end{array}$ & $\mathrm{mg} / \mathrm{L}$ & 16.0 & 62.0 & $31.3 \pm 13.1$ \\
\hline
\end{tabular}

\subsubsection{Results of correlation analyses}

Fig. 4 shows the correlation coefficients $(r)$ and plots of the useful variables. The value of $r$ ranges from $-1-1$, with 0 presenting a zero

correlation and 1 (or -1 ) indicating perfectly correlated variables. The intersections between the rows and columns are $r$ values (number in the square) and scatter plots of the variable pairs and histograms of the variables appear along the matrix diagonal. Hence, on investigating the relationship between the influents, operation parameters, and effluents, we can observe that the HLR had a relatively high correlation with $C_{o n}$ $(r=0.64), C_{o b}(r=0.7), L_{r n}(r=0.46)$, and $L_{r b}(r=0.56)$. The role of HLR in effluent concentration and removal efficiency was also con-

firmed by Kadlec and Knight (1996). A low negative correlation is obtained between $C_{o b}$ and $C_{i b}(r=-0.37)$, which contrasts with the results of the previous studies. Kadlec and Knight (1996) and Babatunde et al. (2011a) stated that $C_{i b}$ had the highest correlation with $C_{o b}$. Some variables such as $C_{i b}$ and $C_{i t s}$ had negative correlations with $C_{o b}$ and $C_{o n}(r$ value from -0.31 to -0.46$)$. In addition, the $\mathrm{pH}$ correlated weakly with all the effluents $\left(L_{r b}, C_{o b}, L_{r n}\right.$, and $\left.C_{o n}\right)$ with a lower $r$ value at 0.1 .

\subsubsection{Results of multiple regression for $\mathrm{BOD}_{5}$}

The output obtained from the LMG analysis (Table 5) indicates that the $64.9 \%$ and $71.7 \%$ of the total variation in $C_{o b}$ and $L_{r b}$, respectively, can be attributed to the seven selected predictor variables. It shows that the $H L R$ can be considered as the most important predictor that ex-plained $39.1 \%$ and $35.6 \%$ of the total variation of $C_{o b}$ and $L_{r b}$, respec- tively. Thus, $C_{i t s}$ and $C_{i b}$ played a smaller role while the $\mathrm{pH}, C_{i n}, C_{i \mathrm{p}}$, and $C_{i t}$ had a weak impact on the variation in response variables. These results demonstrate that there are several factors that influenced the effluent $\mathrm{BOD}_{5}$ of the HCW among which the HLR is an important parameter. Thus, it can be said that the HLR is required to be carefully selected for the design and operation of the HCW system.

Using the seven predictor and response variables of $C_{o b}$ and $L_{r b}$ from Table 5, the HCW data was calculated using the BMA method and summarized in Table 6. Based on the BMA criteria, four optimal models
were selected $(\mathrm{B}-\mathrm{B})$, which have low BIC and high $R^{2}$ results. In re-

ference to $R^{2}, \quad 1 \quad 4 \quad$ et al. (2011) also stated that only an $R^{2}$ Hijosa-Valsero

value greater than 0.50 can be considered as a validation for linear models.

$\mathrm{B}_{4}$ obtained the highest value of $R^{2}(0.7)$, whereas $\mathrm{B}_{3}$ had the lowest BIC (-16.8) which due to fewer variables or more simply. Considering the $R^{2}$ value, these results are lower than those obtained in the study of Babatunde et al. (2011a) $\left(R^{2}=0.86\right)$. It is likely that the HLR was the most important factor that influenced the removal efficiency of the HCW in the case of all the optimal MR models. This result is not in agreement with the study reported by Babatunde et al. (2011a), which concluded that the optimal model for $C_{o b}$ consisted of $C_{i b}, C_{i c}, C_{i n}$, and $C_{i p}$ (not including $H L R$ ). Although the $R^{2}$ values reached $0.6-0.7$, which means that the predictive models explained $60-70 \%$ of the variance of $\mathrm{L}_{\mathrm{rb}}$, these results prove that $\mathrm{B}_{1}-\mathrm{B}_{4}$ are useful models for predicting the removal loading rate of $\mathrm{BOD}_{5}$ of the $\mathrm{HCW}$.

\subsubsection{Results of multiple regression for $\mathrm{NH}_{4}-\mathrm{N}$}

Table 7 shows that $H L R$ and $C_{i t s}$ had high relative importance to $C_{o n}$, which showed a $37 \%$ and $20 \%$ contribution to the total $R^{2}$, respectively. In addition, using the regression model, $C_{i n}$ and HLR explained $60.3 \%$ and $16.2 \%$ of the total variation in $L_{r n}$, respectively. The $\mathrm{pH}$ factor acted as the lowest relative "weight" $(0.08 \%$ and $0.5 \%)$ for the variations of both $\mathrm{C}_{\text {on }}$ and $L_{r n}$.

The results of the BMA method for $\mathrm{N}_{2} \mathrm{H}_{4}-\mathrm{N}$ are presented in Table 8 . 


$\begin{array}{lllll}C_{o n}\left(\mathrm{NH}_{4}-\mathrm{N} \text { outlet }\right. & \mathrm{mg} / \mathrm{L} & 1.6 & 11.5 & 5.3 \pm 2.9 \\ \quad \text { concentration }) & & & & \\ \begin{array}{l}L_{r b}\left(\mathrm{BOD}_{5} \text { removal loading }\right. \\ \text { rate })\end{array} & \mathrm{g} / \mathrm{m}^{2} \cdot \mathrm{d} & 8.8 & 18.6 & 14.5 \pm 2.7 \\ & & & & \\ L_{r n}\left(\mathrm{NH}_{4}-\mathrm{N} \text { removal loading }\right. & \mathrm{g} / \mathrm{m}^{2} \cdot \mathrm{d} & 1.2 & 5.1 & 2.7 \pm 1.0\end{array}$

rate)
Models $\mathrm{B}_{8}-\mathrm{B}_{9}$ had the highest value of $R \quad(0.9)$ and lowest value of BIC ( -40.5 to -43.3$)$. This means that the MR models could explain $90 \%$

of the variation of $\mathrm{L} r$. In addition, the $B_{5}-B_{7}$ tests produced a lower value of $R^{2}$ in the of 0.640 .67 . The of $R^{2}$ in this study are

$$
\text { range } \quad-\quad \text { values }
$$

relatively high as compared with those in the study conducted by Hijosa-Valsero et al. (2011) $\left(R^{2}=0.55\right)$ and (Babatunde et al., 2011a) 


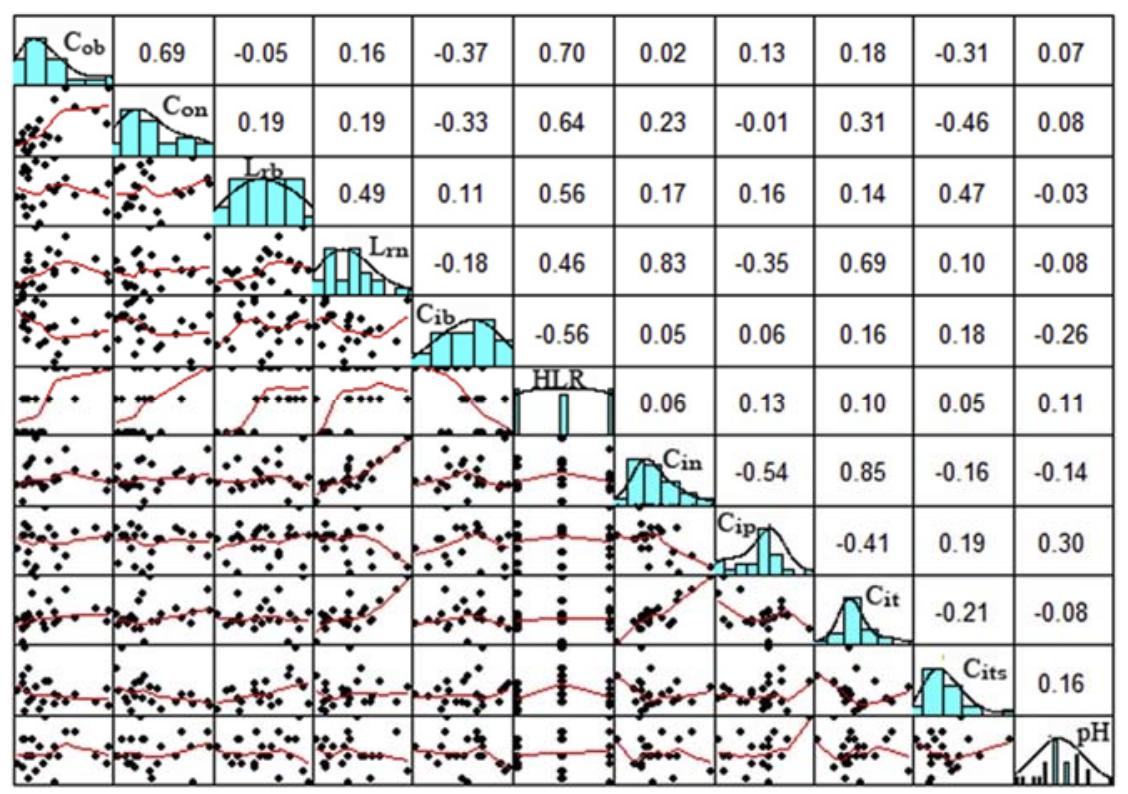

Fig. 4. Correlation matrix of variables.

Table 5

Relative importance of $\mathrm{BOD}_{5}$ effluent and removal rate.

\begin{tabular}{llllllllll}
\hline & Influent & $C_{i b}$ & HLR & $C_{i n}$ & $C_{i p}$ & $C_{i t}$ & $C_{i t s}$ & $\mathrm{pH}$ & Total \\
\hline$C_{o b}$ & Relative importance (\%) & 7.6 & 39.1 & 2.0 & 1.8 & 4.3 & 9.6 & 0.3 & 64.9 \\
$L_{r b}$ & Relative importance (\%) & 8.8 & 35.6 & 3.7 & 2.1 & 2.7 & 18.1 & 0.7 & 71.7
\end{tabular}

Table 6

Optimal models obtained by BMA method for $\mathrm{BOD}_{5}$ effluent and removal rate.

\begin{tabular}{llll}
\hline No. & Equation & $R^{2}$ & BIC \\
\hline $\mathrm{B}_{1}$ & $\mathrm{C}_{\mathrm{ob}}=224.3 H L R-0.22 C_{i t s}+24.9$ & 0.6 & -14.9 \\
$\mathrm{~B}_{2}$ & $\mathrm{C}_{\mathrm{ob}}=247 H L R+0.14 C_{i b}-0.24 C_{i t s}+5.2$ & 0.61 & -12.4 \\
$\mathrm{~B}_{3}$ & $\mathrm{~L}_{\mathrm{rb}}=54 H L R+0.12 C_{i b}+0.05 C_{i t s}-15.2$ & 0.67 & -16.3 \\
$\mathrm{~B}_{4}$ & $\mathrm{~L}_{\mathrm{rb}}=52.2 H L R+0.1 C_{i b}+0.05 C_{i t s}-16.3$ & 0.7 & -14.85 \\
\hline
\end{tabular}

Table 7

Relative importance for $\mathrm{NH}_{4}-\mathrm{N}$ effluent and removal rate.

\begin{tabular}{|c|c|c|c|c|c|c|c|c|}
\hline Influe & & $C_{i b}$ & $H L R$ & $C_{i n}$ & $C_{i p}$ & $C_{i t s}$ & $\mathrm{pH}$ & Total \\
\hline$C_{o n}$ & Relative importance (\%) & 5.7 & 37 & 3.5 & 0.7 & 20.0 & 1.0 & 69.9 \\
\hline$L_{r n}$ & Relative importance (\%) & 2.6 & 16.2 & 60.3 & 7.3 & 3.7 & 0.5 & 90.6 \\
\hline
\end{tabular}

Table 8

Optimal models of BMA method for $\mathrm{NH}_{4}-\mathrm{N}$ effluent and removal rate.

\begin{tabular}{llll}
\hline No. & Equation & $R^{2}$ & $B I C$ \\
& & & \\
\hline$B_{5}$ & $C_{o n}=47.2 H L R-0.07 C_{i t s}+7.1$ & 0.64 & -17.5 \\
$\mathrm{~B}_{6}$ & $C_{o n}=55 H L R+0.04 C_{i b}-0.08 C_{i t s}+0.24$ & 0.67 & -16.0 \\
$\mathrm{~B}_{7}$ & $C_{o n}=46.6 H L R+0.06 C_{i n}-0.07 C_{i t s}+5.5$ & 0.66 & -15.1 \\
$\mathrm{~B}_{8}$ & $L_{r n}=9.4 H L R+0.14 C_{i n}+0.01 C_{i t s}-3.4$ & 0.9 & -43.3 \\
$\mathrm{~B}_{9}$ & $L_{r n}=8.6 H L R+0.14 C_{i n}+0.01 C_{i t s}-0.05 C_{i b}-2.8$ & 0.9 & -41.0
\end{tabular}

$\left(R^{2}=0.69\right)$. All the models reveal that the variances in the effluent $\mathrm{NH}_{4}-\mathrm{N}$ and the removal rate were best explained by the predictor variables of $H L R, C_{i n}, C_{i t s}$, and $C_{i b}$. These predictors are quite different from those of the optimal model of Babatunde et al. (2011a) which included $C_{i t s}, C_{i c}$, and temperature. and removal loading rate of the HCW as well as revealing the overall performance of the HCW.

\subsection{Practical applications and future perspectives}

Previous instances of the use of HCW for sewage wastewater

treatment in Vietnam is still limited, and therefore, there is some doubt regarding the potential of this technology. For the actual conditions of the sewer and local materials, this work demonstrated that the HCW met the current wastewater discharge standards for Vietnam with HLRs of $0.1-0.15 \mathrm{~m} / \mathrm{d}$. Furthermore, in the experiment performed, we also tested the local and new plant named Colocasia esculenta (elephant ear), which demonstrated great potential for wastewater treatment. Thus,

the use of HCW with local plants and materials can replace the cen-

tralized activated sludge wastewater treatment plants that are popular in the cities of Vietnam. Moreover, the use of the statistical method to simulate the HCW performance not only facilitates an investigation of the processes in the HCW but also clarifies the activity trends and the influent parameters. The parameters such as HLR, and TSS had a significant influence on the effluents and will thus be carefully controlled in the real operation of HCWs. Engineers and designers may be able to apply these predictive models for retrofitting or creating more effective HCWs with VF and HF in series.

The new local plant (Colocasia esculenta) might be the first plant used in such an experiment with HCW for wastewater treatment. Although this study might contain insufficient control tests and long-

term observations, the results obtained for the HF and Colocasia esculenta growth demonstrated the great potential of this plant for application to CWs for treating different types of wastewater. Therefore, testing Colocasia esculenta in various types of CW flows and regimes could create more opportunities for enhancing and promoting the performance of HCWs in the real world.

By applying the familiar first-order model for predicting the pollu-

The results of the above analysis indicated that the MR equations of $\mathrm{B}_{5}-\mathrm{B}_{9}$ can be useful for simulating the variances in the $\mathrm{NH}_{4}-\mathrm{N}$ effluents 
tion removal in the HCW, this work demonstrated that the MR method is robust in the modeling of HCW performance as well as for selecting the predictive equations. This research also suggests that studies on the use of MR with more inputs and out parameters of the $\mathrm{HCW}$ may im- prove the understanding of HCWs. Furthermore, it would be interesting to obtain test results for this method over a longer period of operation time in order to develop a superior HCW system. 


\section{Conclusions}

The results obtained for a high removal rate of organic matter and nutrients indicate that the use of HCW can serve as an efficient method of sewage treatment. With high $R^{2}$ values (0.6-0.9) derived from the MR analysis, it is important to note that random noise was not taken into consideration in the investigated models. In all the predictive models, it was observed that the HLR had a dominant impact on the response variables. In general, the MR linear analysis revealed a su- perior ability for prediction of the HCW performance than those of the kinetic rate constant. Models $\mathrm{B}_{1}-\mathrm{B}_{9}$ can be used to evaluate the HCW system performance and predict its output.

\section{Acknowledgment}

This work was supported in part by grants from the Korea Ministry of Environment as an "Algae Monitoring \& Removing Utilization Technology" (Project No. 2015001790001).

\section{Appendix A. Supplementary data}

Supplementary data related to this article can be found at http:/ / dx. doi.org/10.1016/j.jenvman.2018.05.085.

\section{References}

Akratos, C.S., Papaspyros, J.N.E., Tsihrintzis, V.A., 2008. An artificial neural network model and design equations for BOD and COD removal prediction in horizontal subsurface flow constructed wetlands. Chem. Eng. J. 143, 96-110.

Ali, M., Rousseau, D.P.L., Ahmed, S., 2018. A full-scale comparison of two hybrid constructed wetlands treating domestic wastewater in Pakistan. J. Environ. Manag. 210, 349-358.

APHA/WEF/AWWA, 2005. Standard Methods for the Examination of Water \& Wastewater. centennial edition. 21 ed. American Public Health Association, the American Water Works Association, and the Water Environment Federation, Washington DC, USA.

Babatunde, A.O., Zhao, Y.Q., Doyle, R.J., Rackard, S.M., Kumar, J.L., Hu, Y.S., 2011a. On the fit of statistical and the $\mathrm{k}-\mathrm{C}^{*}$ models to projecting treatment performance in a constructed wetland system. J. Environ. Sci. Heal. A. 46, 490-499.

Babatunde, A.O., Zhao, Y.Q., Doyle, R.J., Rackard, S.M., Kumar, J.L., Hu, Y.S., 2011b. Performance evaluation and prediction for a pilot two-stage on-site constructed wetland system employing dewatered alum sludge as main substrate. Bioresour. Technol. 102, 5645-5652.

Chan, S.Y., Tsang, Y.F., Cui, L.H., Chua, H., 2008. Domestic wastewater treatment using batch-fed constructed wetland and predictive model development for NH3-N removal. Process Biochem. 43, 297-305.

Darajeh, N., Idris, A., Fard Masoumi, H.R., Nourani, A., Truong, P., Sairi, N.A., 2016 Modeling BOD and COD removal from Palm Oil Mill Secondary Effluent in floating wetland by Chrysopogon zizanioides (L.) using response surface methodology. J. Environ. Manag. 181, 343-352.

Davoodi, R., Almasi, A., Mohammad,M.,HoseiniAhagh, Dargahi, A.,Karami, A., 2016. A mathematical model for organic matter removal in constructed wetlands case study: wastewater treatment plant of Qasr-E Shirin, Iran. Int. J. Pharm. Technol. 8, 55-67.

Dong, Y., Scholz, M., Harrington, R., 2012. Statistical modeling of contaminants removal in mature integrated constructed wetland Sediments. J. Environ. Eng. 138, 10091017.

Dzakpasu, M., Hofmann, O., Scholz, M., Harrington, R., Jordan, S.N., McCarthy, V., 2011. Nitrogen removal in an integrated constructed wetland treating domestic wastewater. J. Environ. Sci. Health A Tox. Hazard. Subst. Environ. Eng. 46, 742-750.

Fang, X., Li, R., Kan, H., Bottai, M., Fang, F., Cao, Y., 2016. Bayesian model averaging method for evaluating associations between air pollution and respiratory mortality: a time-series study. BMJ Open 8, 1-10.

Gholizadeh, A., Gholami, M., Davoudi, R., Rastegar, A., Miri, M., 2015. Efficiency and kinetic modeling of removal of nutrients and organic matter from a full-scale constructed wetland in Qasre-Shirin, Iran. Environ. Health Eng. Manag. 2 (3), 107-116.

Hijosa-Valsero, M., Sidrach-Cardona, R., Martín-Villacorta, J., Valsero-Blanco, M.C., Bayona, J.M., Bécares, E., 2011. Statistical modelling of organic matter and emerging pollutants removal in constructed wetlands. Bioresour. Technol. 102, 4981-4988.

Hoeting, J.A., Madigan, D., Raftery, A.E., Volinsky, C.T., 1999. Bayesian model averaging: a tutorial. Stat. Sci. 14, 382-417.

Huang, C.-W., Lin, Y.-P., Chiang, L.-C., Wang, Y.-C., 2014. Using CV-GLUE procedure in analysis of wetland model predictive uncertainty. J. Environ. Manag. 140,83-92.

Johnson, J.W., 2000. A heuristic method for estimating the relative weight of predictor variables in multiple regression. Multivariate Behav. Res. 35, 1-19.

Kadlec, R.H., Knight, R.L., 1996. Treatment Wetlands. Lewis Publishers, Boca Raton, FL.

Kadlec, R.H., Wallace, S.D., 2009. Treatment Wetlands, second ed. CRC Press, Florida, USA.

Katz, M.H., 2013. Multivariable analysis: a primer for readers of medical research. Ann. Intern. Med. 138, 644-650.

Keffala, C., Ghrabi, A., 2005. Nitrogen and bacterial removal in constructed wetland treating domestic wastewater. Desalination 185, 383-389.

Melián, J.A.H., Rodríguez, A.J., Arana, J., González Díaz, O., González Henríquez, J.J., 2010. Hybrid constructed wetlands for wastewater treatment and reuse in the Canary Islands. Ecol. Eng. 36, 891-899.

Murray-Gulde, C.L., Bridges, W.C., Rodgers, J.H., 2008. Evaluating performance of a constructed wetland treatment system designed to decrease bioavailable copper in a waste stream. Environ. Geosci. 15, 21-38.

Nguyen, X.C., Nguyen, D.D., Nguyen, T.L., Chang, S.W., 2017. Potential of integrated vertical and horizontal flow constructed wetland with native plants for sewage treatment under different hydraulic loading rates. Water Sci. Technol. 76, 434-442.

Reed, S.C., D, B., 1995. Subsurface flow wetlands-a performance evaluation. Water Environ. Res. 67, 244-248.

Saeed, T., Sun, G., 2011. Kinetic modelling of nitrogen and organics removal in vertical and horizontal flow wetlands. Water Res. 45, 3137-3152.

Samsó, R., García, J., Molle, P., Forquet, N., 2016. Modelling bioclogging in variably saturated porous media and the interactions between surface/subsurface flows: application to Constructed Wetlands. J. Environ. Manag. 165, 271-279.

Sheridan, C.M., Glasser, D., Hildebrandt, D., 2013. Estimating rate constants of contaminant removal in constructed wetlands treating winery effluent: a comparison of three different methods. Process. Saf. Environ. 92, 903-916.

Tchobanoglous, G., Burton, F.L., Stensel, H.D., 2004. Wastewater Engineering: Treatment and Reuse. Metcalf \& Eddy Inc., McGraw-Hill, New York, USA.

Tomenko, V., Sirajuddin, A., Viktor, P., 2007. Modelling constructed wetland treatment system performance. Ecol. Model. 205, 355-361.

Trang, N.T.D., Konnerup, D., Schierup, H.-H., Chiem, N.H., Tuan, L.A., Brix, H., 2010. Kinetics of pollutant removal from domestic wastewater in a tropical horizontal subsurface flow constructed wetland system: effects of hydraulic loading rate. Ecol. Eng. 36, 527-535.

Vaccari, D.A., Storm, P.F., Alleman, J.E., 2006. Environmental Biology for Engineers and Scientists. John Wiley \& Sons, New Jersey, USA.

Vo, T.-D.-H., Bui, X.-T., Nguyen, D.-D., Nguyen, V.-T., Ngo, H.-H., Guo, W., Nguyen, P.-D Nguyen, C.-N., Lin, C., 2018. Wastewater treatment and biomass growth of eight plants for shallow bed wetland roofs. Bioresour. Technol. 247, 992-998.

Vo, T.-D.-H., Do, T.-B.-N., Bui, X.-T., Nguyen, V.-T., Nguyen, D.-D., Sthiannopkao, S., Lin, C., 2017. Improvement of septic tank effluent and green coverage by shallow bed wetland roof system. Int. Biodeter. Biodegr. 124, 138-145.

Vymazal, J., 2005. Horizontal sub-surface flow and hybrid constructed wetlands systems for wastewater treatment. Ecol. Eng. 25, 478-490.

Vymazal, J., 2013. The use of hybrid constructed wetlands for wastewater treatment with special attention to nitrogen removal: a review of a recent development. Water Res. 47 , 4795-4811.

Vymazal, J., Kröpfelová, L., 2015. Multistage hybrid constructed wetland for enhanced removal of nitrogen. Ecol. Eng. 84, 202-208.

Wu, H., Fan, J., Zhang, J., Ngo, H.H., Guo, W., 2018a. Large-scale multi-stage constructed wetlands for secondary effluents treatment in northern China: carbon dynamics. Environ. Pollut. 233, 933-942.

Wu, Y., Liu, J., Rene, E.R., 2018b. Periphytic biofilms: a promising nutrient utilization regulator in wetlands. Bioresour. Technol. 248, 44-48. 